\title{
INPRES NO 14 TAHUN 1967 DAN IMPLIKASINYA TERHADAP IDENTITAS MUSLIM TIONGHOA CIREBON
}

\author{
Popi Siti Sopiah \\ IAIN Syekh Nurjati Cirebon (popisopiah@yahoo.com)
}

\begin{abstract}
At the beginning of the Orde Baru (1966-1998), Soeharto issued a policy of assimilation to Chinese descendants in Indonesia. The aim of the policy is to make Tionghoa culture can be eliminated. The policy of the Soeharto regime was carried out through Instruksi Presiden (Inpres) No. 14 Tahun 1967. Through the policy, the Orde Baru government required all Chinese to assimilate with indigenous people through several things such as Chinese name renaming to indigenous people name, restrictions on Chinese customs movement and Chinese people must follow a religion that recognized by the government. On the basis of that, the researcher is interested to reveal more deeply related to Presidential Instruction No. 14 of 1967 and Its Implications to the Chinese Muslim Identity in Cirebon in Year 1966-1998.
\end{abstract}

Keywords: Chinese Muslims, Orde Baru, Assimilation, Cirebon

\begin{abstract}
Abstrak
Pada awal Orde Baru (1966-1998), Soeharto mengeluarkan kebijakan asimilasi terhadap kelompok keturunan Tionghoa di Indonesia. Tujuan dari kebijakan tersebut agar secara individual sifat-sifat ketionghoaannya mampu dihapuskan. Kebijakan pada rezim Soeharto tersebut dilakukan melalui Instruksi Presiden No. 14 Tahun 1967. Melalui kebijakan tersebut, pemerintah Orde Baru mengharuskan seluruh orang Tionghoa untuk melakukan asimilasi dengan pribumi melalu beberapa hal seperti penggantian nama Tionghoa dengan nama pribumi, pembatasan ruang gerak pada adat istiadat yang berbau Tionghoa serta agama orang Tionghoa yang harus mengikuti agama yang diakui oleh pemerintah. Atas dasar itulah, peneliti tertarik untuk menguak lebih dalam terkait dengan Inpres No 14 Tahun 1967 dan Implikasinya Terhadap Identitas Muslim Tionghoa Cirebon Tahun 1966-1998.
\end{abstract}

Kata Kunci: Muslim Tionghoa, Orde Baru, Asimilasi, Cirebon

\section{A. Pendahuluan}

Pada awal Orde Baru (19661998), Soeharto mengeluarkan kebijakan asimilasi. ${ }^{1}$ Tujuan dari

1 Dalam pandangan Koentjaraningrat asimilasi merupakan suatu proses sosial yang terjadi pada berbagai golongan manusia dengan latar belakang kebudayaan yang berbeda setelah mereka berinteraksi secara intensif, sehingga sifat khas dari unsur-unsur kebudayaan golongan-golongan tersebut masing-masing berubah menjadi unsur-unsur kebudayaan campuran. Nasib Pakpahan, Pengertian

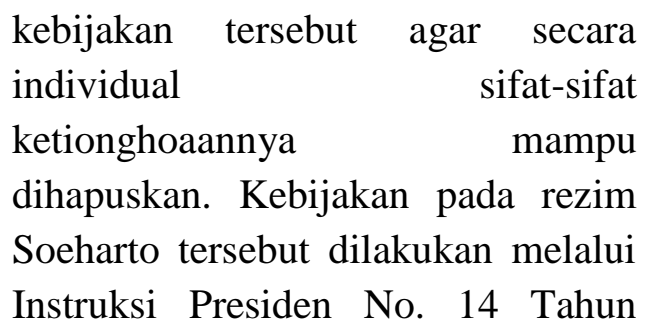

Asimilasi Menurut Para Ahli, http://blogdefinisi.blogspot.co.id/2015/08/pengertianasimilasi-menurut-para-ahli-html? $\mathrm{m}=1$, Diunduh tanggal 07 Maret 2016 pukul 11.00 WIB. 
1967. Adapun isi instruksi tersebut adalah:

"tanpa mengurangi jaminan keleluasaan memeluk agama dan menunaikan ibadatnya, tata cara ibadat Tionghoa yang memiliki aspek kultural pada negeri leluhur, pelaksanaannya harus dilakukan secara intern dalam hubungan keluarga atau perorangan; perayaan-perayaan pesta agama dan adat istiadat Tionghoa dilakukan secara tidak mencolok di depan umum, tetapi dilakukan dalam lingkungan keluarga"2

Keluarnya peraturan yang diskriminatif itu membuat kelompok keturunan Tionghoa mempunyai ruang kebebasan yang sangat sempit. Segala hal yang berhubungan dengan upacara ritual keagamaan, adat istiadat, praktek kebudayaan Tionghoa seperti pertunjukan barongsai, arak-arakan toapekong, ${ }^{3}$

2 Yayasan Kesejahteraan Keluarga Pemuda “66”, Sekitar Pembauran Bangsa di Indonesia, Jakarta: Yayasan Kesejahteraan Keluarga Pemuda “66", 1985, hlm. 342-343.

3 Toa Pe Kong adalah patung dewa dan dewi yang dianggap sebagai penyelamat bagi umat Khonghucu. Antara lain patung Kong Co Hian Thian Siang Tee sebagai Dewa Panglima Perang, patung Mak Co Kwan Im Pou Sat atau Dewi Welas Asih, Mak Co Po Thian Siang Seng Bo atau Dewi Laut, Kong Co Hok Cheng Shin sebagai Dewa Bumi dan Dewa Rezeki serta patung Kwan Tek Kun sebagai Dewa Perang. King Hian, Definisi Toa Pe Kong, http://web.budaya-

tionghoa.net/index.php/item/3649-q-apertanyaan-seputar-dialek-hokkian, Diunduh pada 09 Juli 2016 pukul 13:42. wayang potehi, ${ }^{4}$ dan perayaan Imlek hanya bisa dirayakan dalam lingkungan internal atau keluarga saja. ${ }^{5}$ Sekolah-sekolah yang mengajarkan bahasa dan kebudayaan Tionghoa ditutup dan semua anak sekolah harus pindah ke pengajaran yang disampaikan dalam bahasa Indonesia. Melalui kebijakan asimilasi, pemerintah memutuskan hubungan orang-orang Tionghoa dengan leluhur mereka antara lain melalui penggantian nama bagi yang memakai nama Tionghoa, dan larangan memperdagangkan serta mengedarkan segala jenis barang yang berbau Tionghoa. Organisasi Tionghoa tertentu dilarang. Misalnya organisasi kaum totok seperti perhimpunan masyarakat berdasarkan tempat asal atau organisasi kaum peranakan seperti Badan Permusyawaratan Kewarganegaraan Republik Indonesia (BAPERKI). ${ }^{6}$

\footnotetext{
${ }^{4}$ Wayang Potehi adalah wayang boneka yang terbuat dari kain. Sang dalang akan memasukkan tangan mereka ke dalam kain tsb dan memainkannya seperti layaknya wayang jenis lain. Wayang ini dimainkan menggunakan kelima jari tangan. Tiga jari tengah (telunjuk, jari tengah, dan jari manis) berfungsi mengendalikan bagian kepala wayang, lalu ibu jari dan jari kelingking berperan menggerakkan bagian tangan wayang.

${ }^{5}$ H. Junus Jahja, Masalah Orang Tionghoa di Indonesia, Bandung: Zaman Wacana, 1998, hlm. 87.

6 Michael Jacobsen, Chinese Muslims in Indonesia: Politics, economics, faith and
} 
Namun nampaknya kebijakan asimilasi tersebut tidak memberikan hasil seperti yang diharapkan oleh pemerintah Orde Baru karena adanya keambiguan dalam pelaksanaan kebijakan tersebut. Di satu sisi pemerintah Orde Baru memberikan perhatiannya kepada etnis Tionghoa pada setiap pemilihan umum, bahkan ketika Orde Baru berkuasa juga memberikan kesempatan yang besar kepada etnis Tionghoa untuk berbisnis sehingga muncul kondisi dimana konglomerat dari orangorang Tionghoa ini ada yang beraliansi dengan pemerintah. Di sisi lain, timbulnya diskriminasi dengan mewajibkan adanya Surat Bukti Kewarganegaraan Republik Indonesia (SBKRI). untuk etnis Tionghoa saja sebagai pembuktian kewarganegaraannya meskipun lahir dan secara turun temurun sudah lama hidup di Indonesia.

Kendati etnis Tionghoa sudah lama tinggal di bumi Indonesia, mereka masih menjadi "orang asing" bagi masyarakat pribumi. Mereka juga tidak jarang digunakan sebagai alat adu domba oleh pemerintah. Sikap diskriminatif yang mereka terima baik secara politik maupun sosial, membuat sebagian warga keturunan Tionghoa merasa perlu menyamarkan identitas etnik dan

expediency, dalam Southeast Asia Research Centre, No.54, November 2003, hlm. 9. kebudayaan mereka hanya agar bisa tetap survive di tengah-tengah masyarakat Indonesia seperti mengganti nama Tionghoa mereka dengan nama Indonesia dan sebagian secara resmi juga meninggalkan ajaran Konghucu warisan leluhurnya dan memeluk salah satu agama yang diakui pemerintah Indonesia.

Namun nampaknya kebijakan asimilasi tersebut tidak memberikan hasil seperti yang diharapkan oleh pemerintah Orde Baru karena adanya keambiguan $^{7}$ dalam pelaksanaan kebijakan tersebut. Di satu sisi pemerintah Orde Baru memberikan perhatiannya kepada etnis Tionghoa pada setiap pemilihan umum, bahkan ketika Orde Baru berkuasa juga memberikan kesempatan yang besar kepada etnis Tionghoa untuk berbisnis sehingga muncul kondisi dimana konglomerat dari orangorang Tionghoa ini ada yang beraliansi dengan pemerintah. Di sisi lain, timbulnya diskriminasi dengan mewajibkan adanya $\mathrm{SBKRI}^{8}$ untuk

\footnotetext{
${ }^{7}$ Dalam kamus bahasa Indonesia, kata ambigu berarti memiliki lebih dari satu makna. Jadi, kalimat ambigu berarti kalimat yang memiliki makna ganda atau lebih dari satu arti.

${ }^{8}$ SBKRI merupakan akronim dari Surat Bukti Kewarganegaraan Republik Indonesia atau hasil dari naturalisasi bagi Warga Negara Asing (WNA) yang mendaftar menjadi Warga Negara Indonesia (WNI). Namun demikian kewajiban memiliki SBKRI ini dikhususkan bagi keturunan Tionghoa yang ada di Indonesia. Eddy Setiawan, Waspadai Kebangkitan SBKRI, http://blog-
} 
etnis Tionghoa saja sebagai pembuktian kewarganegaraannya.

Seperti dituturkan Junus Jahja dikutip dari Muhamad Ali dalam Jurnal Chinese Muslim in Colonial and Post Colonial Indonesia:

“...by embracing Islam young ethnic Chinese experienced that immediately they are fully accepted as fellow-Muslims and compatriots by the people at large who are 90 percent Muslims. All kinds of hostility and controversy as an inheritance of the past disappear. They are heartily welcomed now and totally assimilated into the community. So they have at last a permanent 'place in the sun'. This is exactly what ethnic Chinese are so looking and longing for".

Dalam penelitian ini, metode yang digunakan adalah metode historis. Metode ini meliputi pengumpulan sumber, pengujian, dan penganalisaan secara kritis terhadap masa lampau dengan berdasarkan data yang diperoleh. ${ }^{9}$

\section{B. Kehidupan Komunitas Tionghoa Cirebon Sebelum Dikeluarkannya Inpres}

\section{Definisi Orang Tionghoa}

rekamlangkah.blogspot.co.id/2013/09/waspadai -kebangkitan-kembali-SBKRI-html? $\mathrm{m}=1$, Diunduh pada 13 Maret 2016 pukul 08:00 WIB. ${ }^{9}$ Louis Gottschalk, Mengerti Sejarah. Terj. Nugroho Notosusanto, (Jakarta: UI-Press, 1986), hlm. 32.
Ditinjau dari tempat asalnya di wilayah Tiongkok, sub Tionghoa yang bermigrasi ke Indonesia umumnya berasal dari bagian Tenggara Cina yaitu provinsi Guangdong dan Fujian. Penduduk asli daerah tersebut adalah orang Hakka, Hainan, Hokkian, Kanton, Hockchia dan Tiochiu. Dengan demikian Tionghoa yang datang ke kepulauan Nusantara tersebut sebenarnya berasal dari berbagai varian yang berbeda dan kompleks.Dalam berbagai literatur mengenai orang Tionghoa di Indonesia, terdapat sejumlah karya yang memuat mengenai siapa yang dimaksud dengan orang Tionghoa Indonesia.

Dalam pandangan Leo Suryadinata, Masyarakat Tionghoa pada dasarnya merupakan minoritas yang beragam. Mereka terbagi ke dalam kategori peranakan dan totok. Adapun istilah peranakan, Leo Suryadinata memberikan penjelasan secara umum bahwa mereka yang sudah lama tinggal di Indonesia dan umumnya sudah berbaur dengan pribumi. Mereka berbahasa Indonesia sebagai bahasa sehari-hari dan bertingkah laku seperti pribumi. Sementara Tionghoa totok adalah pendatang baru yangatas kemauannya sendiri berdatangan ke Indonesia untuk mencari kehidupan baru pada masa berlangsungnya 
Perang Dunia II. Keturunan orangorang inilah yang sekarang disebut orang-orang Tionghoa totok, uumumnya baru satu sampai dua generasi dan masih berbahasa Tionghoa. $\quad{ }^{10}$ Mereka sudah menganggap diri mereka sebagai orang Indonesia. Namun demikian secara de facto, mereka tetap saja masih dianggap sebagai orang Tionghoa dan dibedakan dari orang Indonesia lainnya.

Menurut Coppel, yang dimaksud dengan orang Tionghoa Indonesia adalah "orang keturunan

10 Tempat lahir orang Tionghoa totok ini berada di luar negeri atau sebagian besar terletak di negeri Tiongkok. Mereka ini bermigrasi ke Indonesia pada abad 19 dan 20 . Kelompok ini merupakan gelombang migrasi terakhir secara besar-besaran. Oleh karena mereka orang Tiongkok asli maka baik bahasa yang digunakan dan kebudayaan yang diekspresikan masih bernuansa Cina. Ringkasnya, mereka ini masih orang Tiongkok. Hal ini ditegaskan secara hukum bahwa mereka ini masih dikelompokkan sebagai warga negara asing (WNA). Orang Tiongkok totok ini kebanyakan bermukim di luar Pulau Jawa. Usia mereka inipun sudah lanjut. Salah satu bukti bahwa mereka masih warga negara asing seperti di wilayah Sidikalang, Sumatera Utara, bagi setiap etnis Tionghoa totok yang ada di sana, di atas pintu rumah bagian depan terdapat tulisan WNA atau warga negara asing. Dengan demikian, etnis Tionghoa totok ini masih merupakan warga negara asing yang memang kebetulan mencari nafkah di Indonesia.Robert Siburian, Etnis Cina di Indonesia: Fakta Komunikasi Antar Budaya, Pusat Penelitian Kemasyarakatan dan Kebudayaan Lembaga Ilmu Pengetahuan Indonesia, hlm 8. LihatLeo Suryadinata, Dilema Minoritas Tionghoa, Jakarta: PT Graifiti Pres,1986, hlm 86.
Tionghoa yang berfungsi sebagai warga atau yang dianggap sebagai orang Tionghoa oleh orang Indonesia dan mendapatkan perlakuan tertentu sebagai akibatnya.Sementara itu yang dimaksud sebagai Muslim Tionghoa dalam pandangan Afthonul Afif adalah mereka yang terlahir sebagai orang Tionghoa baik dari hasil perkawinan antara sesama Tionghoa maupun perkawinan campuran antara orang Tionghoa dengan orang pribumi, dan karena sebab-sebab tertentu kemudian memeluk Islam. ${ }^{11}$

\section{Sejarah kedatangannya di Cirebon}

Kedatangan

orang-orang

Tionghoa di Nusantarasebagaimana yang digambarkan oleh Ma Huan dalam risalah Ying-yai Sheng-lan, bahwa pada abad 15 ia menjumpai orang-orang Tionghoa yang tinggal di sepanjang wilayah pesisir utara Jawa.Cirebon merupakan wilayah persilangan budaya. Tiga diantaranya yaitu budaya Tiongha, India, dan Arab.Ada kemungkinan bahwa orang-orang Tionghoa juga tinggal di Cirebon. Hal itu dapat dibuktikan dengan adanya pemukiman pertama di Cirebon pada kisaran tahun 1415 yang tercatat dalam catatan tahunan

11 Afthonul Afif, Identitas Tionghoa Muslim Indonesia, Depok: Penerbit Kepik, 2012, hlm 173. 
Melayu yang secara khusus membahas tentang Cirebon. ${ }^{12}$

Gelombang kedatangan orangorang Muslim Tionghoa dalam jumlah yang lebih besar baru terjadi di permulaan abad ke 15, yaitu ketika Laksamana Cheng Ho dan para pengikutnya melakukan ekspedisi ke Nusantara. Dalam perjalanan tersebut Cheng Ho telah menyaksikan banyak pemukiman Muslim Tionghoa di berbagai pelabuhan disinggahinya. ${ }^{13}$ Selain aktifitas mereka dalam berbisnis, Muslim Tionghoa juga memiliki peran dalam misi agama yaitu proses masuk dan berkembangnya Islam di Pulau Jawa pada abad ke $15 \mathrm{M}$. Adanya partisipasi orang-orang Tionghoa dalam proses Islamisasi di Kota Cirebon menimbulkan adanya kebudayaan Islam serta kebudayaan Tionghoa seperti pernikahan Sunan Gunung Djati dengan Putri Tan Hong Tien Nio.Peran penting orangorang Tionghoa lainnya adalah banyak dari mereka yang kemudian menjadi syahbandar ${ }^{14}$, pemimpin

${ }^{12}$ HJ.De Graf, CinaMuslim di Jawa antara Abad XV dan XVI, Yogyakarta: PT Tiara Wacana, 2004, hlm 123.

13 Afthonul Afif,Identitas Tionghoa Muslim Indonesia, Depok: Penerbit Kepik, 2012, hlm 7.

14 Istilah syahbandar salah satunya terdapat dalam kamus Hobson-Jobson (A Glossary of Colloquial Anglo-Indian Words and Phrase) yang memberikan contoh terbanyak yang dipetik dari berbagai laporan zaman dulu. Definisi dari syahbandar adalah "Raja pelabuhan, atau bahkan mendapatkan jabatan resmi di kesultanan. Tercatat bahwa Tan Sam Tjay ${ }^{15}$ pernah diangkat menjadi bendahara kerajaan pada masa Sunan Gunung Djati.Ia berperan penting dalam pembuatan desain Goa Sunyaragi sehingga ia diberi gelar Tumenggung Arya Wiratjula. ${ }^{16}$
Interaksi

Tionghoa dengan melahirkan asimilasi melalui kontak dagang dan pernikahan. Banyak orang-orang Tionghoa yang menikah dengan pribumi dengan bertujuan untuk mengenalkan Islam,sekaligus membentuk ikatan sosial yang lebih dekat antara orang-orang Tionghoa

pelabuhan, Penguasa pelabuhan". Syahbandar diambil dari bahasa Persia yaitu Shah=raja dan bandar=pelabuhan. Lihat Henri Chambert Loir dalam Hasan Muarif Ambary, Panggung Sejarah, Jakarta: Yayasan Pustaka Obor, 2011, hlm 262-263

${ }^{15}$ Dalam buku Cina Muslim di Jawa adab XVXVI, HJ De Graff mengungkapkan bahwa dalam catatan Melayu, Sam Tjay Kong aslinya bernama Tan Sam Cai dengan nama muslim Muhammad Syafi'i. Dia menjadi Menteri Keuangan Keraton Kasepuhan Cirebon sepeninggal Sunan Gunung Djati. Disebutsebut, Sam Tjay Kong alias Tan Sam Cai alias Muhammad Syafi'i, menjadi bendahara cakap dan terpercaya pada masa transisi ketika Kesultanan Cirebon di bawah Panembahan Ratu, pengganti sementara Sunan Gunung Djati yang telah wafat.

${ }^{16}$ Nurdin M.Noer, Menusa Cirebon, Cirebon: Dinas Pemuda dan Pariwisata Kota Cirebon, 2009, hlm 98. 
dengan penduduk Cirebon. ${ }^{17}$ Selain tokoh-tokoh di atas, sumber lain yang menunjukkan eksistensi Muslim Tionghoa di Cirebon adalah benda arkeologis seperti bangunan masjid,di mana keramik dan motif bangunan khas Tiongkok menghiasi setiap struktur bangunannya. ${ }^{18}$

\section{Kilas Balik Sejarah Tionghoa di Indonesia}

Pada awal abad ke 19, pemerintah Hindia Belanda memberlakukan peraturan dengan membagi penduduk di wilayah tersebut menjadi tiga golongan yaitu golongan Eropa, golongan Timur Asing yang di dalamnya terdapat kelompok Tionghoa, Arab dan lainnya serta kelompok ketiga adalah penduduk pribumi. Pengelompokan ini sebenarnya bertujuan memudahkan dalam pengawasan administrasi sipil. Tetapi dalam perkembangannya, penggolongan ini berimplikasi sangat luas karena merembet pada masalah sosial, ekonomi, budaya dan kemasyarakatan. Pembentukan lembaga mayor dan kapten ${ }^{19}$ Cina

${ }^{17}$ Nurdin M, Noer, Menusa Cirebon, Cirebon: Dinas Kebudayaan dan Pariwisata Kota Cirebon, 2009, hlm 98

${ }^{18}$ H.J De Graff dkk. Cina Muslim di Jawa Abad $X V$ dan XVI, Yogyakarta: PT Tiara Wacana, $2004 \mathrm{hlm}$

${ }^{19}$ Istilah Kapitein ( Kapitan-Indonesia), berasal dari bahasa Spanyol untuk "Kapten", tapi dalam hal ini tidak ada hubungannya dengan urusan militer. Kapten adalah sebuah gelar yang dan pembatasan ruang gerak melalui pas jalan untuk bepergian dari satu tempat ke tempat lainnya, mengakibatkan ruang gerak masyarakat Tionghoa dalam mencari penghidupan menjadi terbatas. Akibatnya mereka hanya dapat melakukan kegiatan perdagangan dalam upaya penghidupan mereka.

Otoritas kolonial merasakan ancaman dengan kondisi tersebut. Akhirnya strategi untuk mengerdilkan orang Tionghoa ditempuh dengan cara memanfaatkan lebarnya kesenjangan kesejahteraan antara orang Tionghoa dengan kelompok pribumi sebagai alat untuk menghembuskan isu bahwa kesengsaraan warga pribumi disebabkan oleh ketamakan orangorang Tionghoa. Kelompok pribumi akhirnya terhasut dan mengakibatkan terjadinya peristiwa Chinezemoord atau Geger Pecinan pada tahun 1740 di Batavia. ${ }^{20}$

diberikan kepada kepala kelompok ras (dalam hal ini kelompok Tionghoa). Seorang Kapten diberikan kekuasaan oleh pemerintah kolonial untuk mengatur urusan kelompok ras tersebut yang berkenaan dengan agama dan adat istiadat. Ia juga diharapkan untuk menyelesaikan pertikaian diantara kelompok rasnya sehubungan dengan hukum adat, Leo Suryadinata, Negara Dan Etnis Tionghoa, 2002, LP3ES, Jakarta, hlm 12

20 Peristiwa ini juga dikenal denan 'Tragedi Angke' dimana pribumi bersama serdadu VOC membantai setiap orang Tionghoa yang mereka jumpai, membakar rumah-rumah, gudang logistik, dan menjarah aset-aset Tionghoa di 
Pada masa itu Muslim Tionghoa yang ada di Cirebon juga mengalami kesulitan untuk berkembang karena adanya tekanan dari Belanda. Di sini kemudian banyak orang Tionghoa yang mengikuti alur politik Belanda dengan memeluk agama Kristen atau Katolik yang identik dengan agama mayoritas orang Eropa.Hal tersebut disebabkan pula karena masih adanya sikap permusuhan kepada orang-orang Tionghoa yang dapat menciptakan sumber ketegangan. Karena itu, keamanan menjadi sesuatu yang sangat berharga. Mereka memandang bahwa dengan memeluk agama yang dipegang oleh penguasa pada masa itu dapat memberikan perlindungan serta rasa aman. $^{21}$

Sebagian orang Tionghoa memilih untuk masuk Islam dan menolak memakan daging babi dan mengikuti seluruh ada-istiadat penduduk asli. Banyak dari mereka yang memeluk agama Islam sebagai akibat peristiwa Pembantaian 1740 dan juga untuk menghindari pajak yang khusus dikenakan kepada orang-orang Tionghoa. Karena jumlah orang Tionghoa yang

Batavia. Sebanyak 10.000 manusia menjadi korban jiwa dalam tragedi ini. Lihat Afthonul Afif, Identitas Tionghoa Muslim, Depok: Penerbit Kepik, 2012, hlm 52

${ }^{21}$ Afthonul Afif, op.cit, hlm 10. memeluk Islam semakin banyak, VOC memisahkan mereka dari masyarakat Tionghoa yang bukan muslim dan menyerahkan pengurusan dan pengawasan mereka kepada seorang kapiten Tionghoa yang diangkat dari kalangan mereka sendiri. Tetapi jabatan mayor atau kapiten dalam masyarakat muslim Tionghoa di Batavia dihapuskan pada 1827. Setelahnya, mereka menjadi muslim sulit dibedakan lagi dari penduduk asli yang beragama Islam.

Setelah tragedi chinezemoord tersebut, orang Tionghoa memutuskan untuk menjauhi politik dan berkonsentrasi pada ekonomi. Mereka pun menerima begitu saja kebijakan-kebijakan diskriminatif pemerintah Belanda salah satunya dengan mengisolasi mereka ke dalam perkampungan-perkampungan khusus yang kelak disebut pecinan. Kebijakan ini diambil pemerintah kolonial agar bisa membendung kemungkinan-kemungkinan

bersatunya orang-orang Tionghoa dengan pribumi melawan Belanda. ${ }^{22}$

Menjelang akhir abad 18, orang-orang Tionghoa segera memulihkan kembali citra positif mereka sebagai rekan paling strategis pemerintah Belanda dalam hal menjaga stabilitas aktifitas

${ }^{22}$ Daradjadi,Geger Pecinan 1740-1743, Jakarta: PT Kompas Media Nusantara,2012,hlm 27. 
perdagangan. Namun pemerintah kolonial justru memanfaatkan kesetiaan dan keterampilan orang Tionghoa ini sebagai sumber pendapatan kas pemerintah kolonial dengan memperalat Tionghoa sebagai perantara mereka dengan penduduk pribumi untuk hal-hal pengelolaan atas jalan tol, rumah gadai, dan lain-lain. Orang-orang Tionghoa pun ikut memanfaat kesempatan tersebut untuk menjadikan perekonomian mereka semakin kaya serta kecenderungan untuk menciptakan keamanan. Kondisi ini yang kemudian membuat orang-orang Tionghoa semakin merapat dan berusaha tetap mempertahankan hubungan baik dengan pihak kolonial.

Namun pada tahun 1823, pemerintah kolonial di bawah Gubernur Jenderal Van Der Capellen mengeluarkan peraturan yang melarang penyewaan tanah kepada orang Tionghoa. Kondisi ini membuat orang Tionghoa yang sebelumnya berkecimpung dalam bidang pertanian beralih profesi sebagai pedagang. Hasil-hasil pertanian mereka menyebar sampai ke pelosok desa. Akibatnya justru dominasi ekonomi di pedesaanpun akhirnya dikuasai oleh orang Tionghoa. Mereka menguasai jalur produksi hingga distribusi karena bahan mentah mereka beli lalu kemudian mereka olah dan akhirnya mereka pula yang menjualnya secara langsung. ${ }^{23}$

Secara perlahan para pedagang Tionghoa menjadi sebuah kelompok yang memiliki kemampuan tinggi dalam bidang perdagangan yang pada gilirannya menjadikan kelompok ini sebagai tulang punggung ekonomi di mana hampir seluruh denyut kehidupan bergantung. Posisi penting dalam bidang ekonomi menjadikan mereka seolah anak emas bagi para penguasa, baik pemerintah kolonial maupun para penguasa lokal. Tidak mengherankan jika pada tahun 1619 , kelompok Tionghoa yang berdomisili di wilayah Banten menjadi rebutan antara Sultan Banten dengan VOC.

Peristiwa dan pengalaman pada masa kolonial tersebut menjadikan kelompok Tionghoa mendapat label sebagai sebuah kelompok masyarakat yang harus diperlakukan khusus, yang dapat bermakna positif sebagai pemegang gerak roda ekonomi maupun makna negatif pendiskriminasian dan

23 Priyanto Wibowo, Tionghoa Dalam Keberagaman Indonesia: Sebuah Perspektif Historis Tentang Posisi Dan Identita, dalam Jurnal Prosiding The $4^{\text {th }}$ International Conference on Indonesian Studies: "Unity, Diversity and Future", 2010, Fakultas Ilmu Budaya Universitas Indonesia, hlm 6. 
pemencilan, dimana keduanya hampir selalu berkaitan satu sama lain. Dari sinilah kemudian berturutan memunculkan label-label lain yang arahnya selalu bermuara pada perekonomian, kesenjangan,

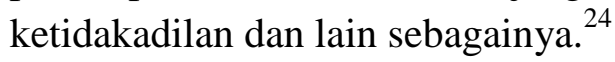

Kemudian pada waktu diselenggarakan perundingan Linggarjati pada tanggal 10 November 1946 antara pemerintah Indonesia dengan Belanda yang menghasilkan kesepakatanbahwa Belanda mengakui wilayah kekuasaan RI di Sumatra, Jawa dan Madura dan mereka harus meninggalkan daerah tersebut paling lambat tanggal 1 Januari 1949. Namun Belanda kemudian melanggar kesepakatan itu pada 21 Juli 1947 dengan melancarkan aksi militer ke beberapa wilayah di Indonesia termasuk kota Cirebon menjadi sasarannya.

Serangan Belanda dilancarkan dari udara maupun darat. Serangan ini mendapatkan perlawanan dari TNI. Namun karena kekuatan yang tidak seimbang maka tentara Belanda berhasil menduduki kota Cirebon. Sebagian anggota TNI mundur ke

${ }^{24}$ Abdul Wahid Dari Depresi Ekonomi hingga Dekolonisasi: Pengusaha Tionghoa dan Industri Batik Cirebon, tahun 1930an-1950an. Makalah ini dipresentasikan dalam workshop Dekolonisasi dan Posisi Etnis Tiongho Indonesia 1930an - 1960an, NIOD-Univ. Negeri Padang, Padang, 19-21 Juni 2006, hlm 6. lereng Gunung Ciremai di Kuningandan sebagian lagi tetap bersembunyi di kota dan sekitarnya. Sementara itu, situasi tidak menentu dan keamanan yang buruk terus mewarnai Trusmi selama masa perang gerilya. Akibatnya banyak diantara penduduk desa yang pergi mengungsi ke tempat saudaranya di daerah lain.

Semua sektor kehidupan, terutama bidang perekonomian hampir tidak bisa berjalan. Pencurian dan kriminalitas merajalela dan akhirnya mencapai puncaknya pada pertengahan Desember 1948, ketika sekelompok masyarakat melakukan penyerangan terhadap orang-orang Tionghoa yang tinggal di Trusmi dan Karang Tengah.Terlepas dari siapa sebenarnya pelaku penyerangan, pembakaran dan pembunuhan terhadap orang Tionghoa di Trusmi, peristiwa itu telah memberikan dampak penting bagi kehidupan masyarakat setempat yang merupakan puncak ketegangan kultural antara kelompok pendatang dan kelompok pribumi yang secara laten telah dirasakan sejak periode akhir kolonial. Pertama, berkembangnya stigma orang-orang Tionghoa itu sebagai pengkhianat revolusi. Mereka diklaim sebagai mata-mata Belanda dan mendukung kembalinya kekuasaan Belanda di Indonesia. Kedua, muncul anggapan 
bahwa orang-orang Tionghoa adalah penjajah ekonomi. Memang selama masa kolonial, mereka banyak memperoleh keuntungan ekonomis melalui hak-hak istimewa yang diberikan oleh penguasa Belanda.Singkatnya faktor etnik dan ekonomi tidak jarang diselimuti oleh isu dalam memainkan dan mendorong masyarakat setempat untuk melakukan aksi kekerasan tersebut. ${ }^{25}$

Belajar dari pengalaman dan peristiwa pada masa kolonial, pemerintahan dan penguasa pada periode sesudah Belanda juga melakukan hal serupa. Penguasa pendudukan Jepang yang sangat singkat, mengeluarkan UU yang mengatur posisi Tionghoa. Dalam UU No. 7 yang dikeluarkan pada tanggal 11 April tahun 1942, orang Tionghoa digolongkan sebagai bangsa asing dan oleh karena itu mereka harus membayar apa yang dinamakan pajak bangsa asing. Selain itu, setiap Tionghoa dewasa yang hendak bepergian diwajibkan membawa kartu pengenal sebagai orang asing dan surat jalan. ${ }^{26}$

\footnotetext{
${ }^{25}$ Abdul Wahid, Ibid,hlm 6

26 Priyanto Wibowo, Tionghoa Dalam Keberagaman Indonesia: Sebuah Perspektif Historis Tentang Posisi Dan Identita, dalam Jurnal Prosiding The $4^{\text {th }}$ International Conference on Indonesian Studies: "Unity, Diversity and Future", 2010, Fakultas Ilmu Budaya Universitas Indonesia, hlm 10.
}

Untuk melokalisir kegiatan ekonomi Indonesia, pemerintah Jepang membentuk koperasi guna mengontrol perekonomian hingga tingkat desa. Orang Tionghoa dilibatkan dan bahkan diberi peran khusus. Beikoku Kouri Kumiaiatau Koperasi Pedagang Beras yang merupakan bagian dari politik distribusi makanan yang diterapkan pemerintah pendudukan Jepang, dioperasikan oleh seorang direktur yang direkrut dari Tionghoa yang sudah lama berkecimpung dalam perdagangan beras. Kondisi demikian makin menajamkan posisi Tionghoa pada jaman tersebut karena mereka dibenturkan langsung dengan masyarakat pada umumnya yang sedang kesulitan bahan makanan. ${ }^{27}$

\section{Kehidupan Komunitas Muslim Tionghoa Cirebon
a. Aktifitas Sosial dan Budaya

Sejak kedatangannya ke Cirebon, orang-orang Tionghoa sudah membaur dengan penduduk setempat. Hasilnya adalah terjadinya pembauran di bidang kehidupan mereka dan juga melakukan asimilasi alami. Masyarakat Tionghoa telah menyatu dengan penduduk setempat dan mengalami pembauran lewat perkawinan.

\footnotetext{
${ }^{27}$ Priyanto Wibowo, Ibid, hlm 12.
} 
${ }^{28}$ Mayoritas penduduknya sudah merupakan penduduk peranakan, yaitu lahir di Indonesia. Kesenian maupun upacara tradisi yang dilestarikan oleh masyarakat keturunan Tionghoa, antara lain upacara Imlek menyambut datangnya tahun baru dengan dimeriahkan kesenian barongsai dan liong. ${ }^{29}$

Kedatangan orang-orang

Tionghoa ke Indonesia khususnya Cirebon membawa serta tradisi, tata kehidupan serta norma-norma yang berlaku dalam masyarakat asal mereka serta sikap fanatisme terhadap tradisi negara leluhur.Menurut Hari Saputra Gani, dalam melakukan aktifitas budayanya ada beberapa Muslim Tionghoa dan Tionghoa non Muslim yang masih ikut mengelola secara bersama-sama setiap ritual keagamaan maupun dalam menjalankan tradisi adat. 30 Meskipun telah menjadi muslim, aktivitas keagamaan dan budaya tersebut masih dipegang kuat oleh Hari Saputra Gani sebagai bentuk penghormatan terhadap siapa

${ }^{28}$ Wawancara dengan Pak Darma Suryapranata di kediaman narasumber Jl. Siliwangi no 54 tanggal 06 Juni 2016 pukul 11.00 WIB.

${ }^{29}$ Barongsai yaitu tarian tradisional Tionghoa dengan menggunakan sarung menyerupai singa

${ }^{30}$ Wawancara dengan Pak Hari Saputra Gani di kantor DPRD Kota Cirebon tanggal 15 Juli 2016 pukul 14:30 WIB. leluhurnya sekaligus dijadikan sebagai momen yang penting untuk tetap menjaga keharmonisan bersaudara di tengah karakter keluarganya yang memiliki keyakinan secara heterogen. ${ }^{31}$

Kondisi ini menunjukkan bahwa aktifitas budaya dan ritual keagamaan bisa menjadi wadah interaksi sosial masyarakat yang berbeda agama maupun etnis. Mereka bersikap saling menghormati dan mendukung dalam melakukan tradisi yag terdapat persamaan nilainilainya. Aktifitas budaya tersebut baik di tradisi orang Tionghoa seperti perayaan Imlek, Barongsai, Chen Beng ${ }^{32}$, maupun sebaliknya ketika Muslim Tionghoa merayakan Idul Fitri dan ziarah kubur.

\section{b. Aktifitas Sosial dan Budaya}

Meskipun Etnis Tionghoa dianggap sebagi warga pendatang tetapi etnis Tionghoa lebih berhasil dalam bidang ekonomi dibanding masyarakat pribumi pada umumnya. Prototipe sifat etnis Tionghoa yaitu rajin, ulet, hemat dan dapat dipercaya di dalam berdagang yang berada di Cirebon, begitu melekat

\footnotetext{
${ }^{31}$ Wawancara dengan Pak Hari Saputra Gani di kantor DPRD Kota Cirebon tanggal 15 Juli 2016 pukul 14:30 WIB.

32 Pak Hari menjelaskan bahwa Chen Beng yaitu tradisi mengunjungi makam keluarga dengan tujuan untuk berdoa yang dalam Islam dikenal dengan ziarah kubur.
} 
dalam pandangan kaum pribumi. Sebagian besar mereka adalah termasuk kelompok Hokkian. ${ }^{33}$ Usaha-usaha tersebut dapat dijumpai di pusat-pusat perdagangan dan perbelanjaan di daerah Cirebon.Secara umum mata pencaharian Muslim Tionghoa adalah pedagang dan pengusaha. Walaupun telah beragama Islam, mereka mengakui bahwa ajaran Tri Dharma $^{34}$ telah memberikan pengaruh yang sangat besar terhadap setiap aspek kehidupan Etnis Tionghoa. Misalnya, sifat dapat dipercaya membuat eksitensi mereka

33 King Hian, Budaya Tionghoa, Orang Hokkian (Hanzi: 福建人, pinyin: fujian ren) atau Orang Hoklo adalah penduduk dari provinsi Fujian bagian selatan di Republik Rakyat Tiongkok. Banyak orang Hokkian menjadi perantau dan tinggal di berbagai negara, terutama di Asia Tenggara dalam http://web.budaya-

tionghoa.net/index.php/item/3649-q-a-

pertanyaan-seputar-dialek-hokkian Diakses pada 09 Juli 2016 pukul 13:42 WIB.

34 Seputar Tionghoa.info, Tridharma Masa Kini, Tridharma (Hanzi: 三教, hanyu pinyin: sanjiao) adalah sebuah kepercayaan yang tidak dapat digolongkan ke dalam agama apapun. Tridharma disebut Samkau dalam dialek Hokkian, berarti harfiah tiga ajaran. Tiga ajaran yang dimaksud adalah Taoisme, Buddhisme dan Konfusianisme. Tridharma lebih tepat disebut sebagai salah satu bentuk kepercayaan tradisional masyarakat Tionghoa sebagai hasil dari sinkretisme ketiga filsafat yang mempengaruhi kebudayaan Tionghoa dan sejarah Tiongkok sejak 2500 tahun lalu. http://www.tionghoa.info/fengshui/, Diakses pada 09 Juli 2016 pukul 13:48 WIB. dalam bidang perdagangan selalu berkembang pesat.

\section{Seputar Instruksi Presiden No. 14 Tahun 1967}

\section{Identitas Tionghoa pada masa Orde Lama}

Periode revolusi kemerdekaan merupakan bagian penting dari sejarah Indonesia yang diisi oleh perjuangan bangsa dari berbagai sektor seperti militer, diplomasi, jurnalisme dan lain-lain. Perjuangan tersebut terutama ditujukan untuk mempertahankan kemerdekaan yang telah diproklamirkan serta menjaga dari ancaman kolonialisme Belanda yang mencoba untuk menjajah kembali. Berbagai komponen bangsa turut memberikan sumbangsih dalam revolusi tersebut, diantaranya adalah masyarakat Tionghoa. Orang Tionghoa sebagaimana kelompok masyarakat Indonesia lainnya dalam tahap awal berdirinya Indonesia merasa bahwa Indonesia adalah tanah air mereka yang kedaulatannya wajib mereka bela.

Kesadaran politik masyarakat Tionghoa mulai tumbuh pada awal abad 20. Pada masa itu paham nasionalisme yang berorientasi ke Tiongkok mulai dianut oleh sebagian orang Tionghoa. Sebagian di antaranya adalah kaum peranakan yang memandang dirinya sebagai bagian dari bangsa Tionghoa. 
Sebagai wadah aspirasi, mereka mendirikan organisasi seperti Tiong Hoa Hwee Koan ${ }^{35}$ pada tahun 1900. Gagasan nasionalisme yang berorientasi ke Tiongkok semakin terekspresikan dengan terbitnya koran Sin $\mathrm{Po}^{36}$ pada tahun 1910. Melalui koran tersebut, para pendukung koran ini beranggapan bahwa dalam masalah kewarganegaraan, orang Tionghoa di Indonesia yang saat itu dijajah oleh Belanda adalah rakyat Tiongkok dan bukan kawula Belanda.

Meski demikian, tidak semua orang Tionghoa adalah pendukung nasionalisme yang berorientasi ke Tiongkok. Mereka adalah kaum peranakan yang mendapatkan pendidikan Belanda. Pada tahun 1928 kelompok ini mendirikan Partai Chung Hwa Hui dan mereka berpendapat bahwa peranakan Tionghoa adalah kawula Belanda dan harus ikut serta dalam

35 Pada mulanya THHK bertujuan untuk memperbaiki kebiasaan orang Tionghoa yang berdasarkan pada ajaran Konfusianisme. Dalam perkembangannya THHK menjadi sebuah perkumpulan yang ingin memajukan pendidikan orang Tionghoa. Leo Suryadinata, Negara dan Etnis Tionghoa, Jakarta: LP3ES, 2002 hlm 25.

${ }^{36}$ Sin Po merupakan koran yang diterbitkan oleh orang Tionghoa dengan menggunakan bahasa Melayu dan Mandarin. Tahun 1911 koran Sin Po menjadi percetakan yang awalnya terbit setiap minggu menjadi terbit setiap hari. Leo Suryadinata, Ibid, hlm 38. pemerintahan untuk membela kepentingan Belanda. ${ }^{37}$

Situasi sedikit berubah pada masa pendudukan Jepang. Penguasa Jepang mengeluarkan kebijakan untuk menutup seluruh koran yang diterbitkan oleh orang Tionghoa dan melarang orang Tionghoa untuk melakukan kegiatan politik. Sekolahsekolah berbahasa pengantar Belanda juga ditutup, Hal itu menyebabkan kekuatan kelompok Chung Hwa Hui semakin lemah. Sementara itu, beberapa tokoh Sin Po kelompok yang berorientasi ke Tiongkok, ditangkap. Jikapun tidak tertangkap, sebagian dari mereka ada yang melarikan diri. Sedangkan kelompok PTI yang berorientasi nasionalisme Indonesia dibubarkan. Pemerintah Jepang menyatukan seluruh organisasi Tionghoa ke dalam satu wadah yang diberi nama Hua Ch'io Tsung Hui (HTCH) yang pemimpinnya ditunjuk oleh Jepang dan bertanggung jawab kepada mereka.

Menjelang akhir Perang Dunia II, posisi Jepang di Asia semakin terdesak. Akibat dari situasi ini, pada bulan Maret 1945 Jepang mendirikan Badan Penyelidik Usaha-Usaha Kemerdekaa Indonesia (BPUPKI)

37 Leo Suryadinata, Tokoh Tionghoa dan Identitas indonesia: dari Tjoe Bou San sampai Yap Thiam Hien, Jakarta: Komunitas Bambu, 2010 hlm 53. 
dalam rangka untuk mendapat dukungan dari rakyat.

Dalam setiap rapat BPUPKI, Liem Koen Hian sering mengemukakan pendapatnya yang mendukung secara penuh kemerdekaan Indonesia. Ia juga berpendapat bahwa masyarakat Tionghoa di Indonesia tidak lagi menganut kebudayaan Tionghoa dan menekankan bahwa masyarakat Tionghoa lebih menjadi Indonesia daripada Tiongkok. Dalam pandangan Liem, Republik Indonesia yang akan dibentuk harus mengakui semua orang Tionghoa sebagai warga negara Indonesia.

Sementara perwakilan Partai Chung Hwa Hui dalam BPUPKI adalah Oei Tjong Hauw. Tentang masalah kewarganegaraan, ia menganjurkan agar pemerintah Indonesia yang akan terbentuk nanti untuk menyatakan bahwa semua warga Tionghoa yang ada di Indonesia adalah warga Tiongkok. Ia mengemukakan bahwa setelah pendudukan Jepang, UndangUndang Kekaulaan Belanda tidak akan berlalu lagi. Oei Tjong Hauw, mantan pemimpin Chung Hwa Hui $(\mathrm{CHH}),{ }^{38}$ beranggapan bahwa

${ }^{38}$ Chung Hwa Hui adalah bentuk nasionalisme etnis Tionghoa yang berorientasi pada Belanda. Partai politik ini didirikan pada tahun 1928. Gerakan ini mendapatkan dukungan dari kalangan intelektual peranakan. Kelompok ini menganjurkan untuk menerima status menjadi seluruh orang Tionghoa akan menjadi warga negara Tiongkok meskipun mereka tinggal di Indonesia dan orang Tionghoa lokal harus diizinkan untuk memilih warga negara Indonesia atau Tiongkok.

Di masa demokrasi terpimpin, golongan etnis Tionghoa mendapatkan peran dan pengaruh politik Inodesia, seperti adanya beberapa menteri dari etnis Tionghoa salah satunya ialah Oei Tjoe Tat Yan yang menjadi menteri dalam kabinet Soekarno. Ia bahkan menjadi tangan kanan Soekarno terutama ketika terjadi Konflik dengan Malaysia. Untuk membela keturunan Tionghoa dari diskriminasi aturan negara, pada tahun 1948 dibentuk Badan Permusyawaratan Kewarganegaraan Turunan Tionghoa (Baperwat). Namun karena masih menggunakan kata "Tionghoa", akhirnya mereka sepakat untuk merubah nama organisasi menjadi Badan Permusyawaratan Kewarganegaraan Indonesia (BAPERKI) yang diketuai oleh Siauw Giok Tjhan dan wakilnya Yap Thiam Hien.

Soekarno pernah mengeluarkan kebijakan untuk mengatur status kewarganegaraan

kawula Belanda dan aktif berpartisipasi dalam lembaga-lembaga politik seperti Volksraad (Dewan Rakyat). LeoSuryadinata, Pemikiran Politik Etnis Tionghoa Indonesia1900-2002, Jakarta: LP3ES, 2005 hlm. 47. 
bagi etnis-etnis pendatang melalui Undang-Undang Kewarganegaraan tahun 1948 yang dilandaskan pada azaz Ius soli dan "sistem pasif." Undang-undang itu menyebutkan bahwa warga negara Indonesia terdiri dari orang asli yang bertempat tinggal Indonesia. Atas dasar itu, mayoritas etnis Tionghoa yang tinggal di Jawa secara otomatis menjadi Warga Negara Indonesia. Jelas bahwa melalui Undang-Undang Kewarganegaraan tersebut warga Tionghoa diterima sebagai bagian "seutuhnya" dari penduduk Indonesia yang baru merdeka dan persoalan etnisitas tidak dipermasalahkan. ${ }^{39}$

\section{Latar Dikeluarkannya Inpres No 14 Tahun 1967}

Zaman Orde Baru dimulai ketika Soeharto menjabat sebagai Presiden. Pada masa inilah munculnya penerapan kebijakan yang melarang segala hal yang identik dengan Tionghoa. Sebuah rezim pro-Barat yang berdiri dipimpin Soeharto kemudian membawa Indonesia menjadi negara yang diskriminatif terhadap etnis Tionghoa. ${ }^{40}$

\footnotetext{
${ }^{39}$ Wawancara dengan Pak Darma Suryapranata di kediaman narasumber Jl. Siliwangi no 54 tanggal 06 Juni 2016 pukul 11.00 WIB.

40 Nurani Soyomukti, Soekarno dan Cina, Yogyakarta: Penerbit Garasi, 2002, hlm 34.
}

Orde Baru di bawah pimpinan Soeharto menaruh curiga atas hubungan-hubungan yang dijalin oleh komunitas Tionghoa di Indonesia dengan Republik Rakyat Cina. RRC dituding sebagai salah satu negara komunis di belakang G30S/PKI. Upaya memblokir hubungan antara keturunan Tionghoa di Indonesia dengan RRC dilakukan untuk mencegah penyusupan paham komunisme Tiongkok ke Indonesia. ${ }^{41}$ Berbagai peristiwa antiTionghoa terjadi di beberapa belahan Indonesia sampai dengan tahun 1967. Pada periode ini juga menandai berakhirnya organisasiorganisasi "politik" Tionghoa, karena BAPERKI dibubarkan dan sebagian anggotanya ditangkap, disiksa, dipenjarakan atau dibunuh. ${ }^{42}$ Sejak awal berdirinya pemerintahan Soeharto, ada keyakinan umum bahwa keturunan Tionghoa tidak memiliki sentimen kebangsaan. Orang-orang keturunan Tionghoa dicurigai telah mendukung

41 Meskipun Baperki memilih ideologi kiri, organisasi ini berhasil mempertahankan kedudukannya sebagai perwakilan yang menonjol dari warga negara Indonesia Tionghoa. Organisasi khususnya tetap menerima dukungan dari mayoritas masyarakat Tionghoa karena kegiatannya tidak terbatas pada lingkar kegiatan politik. Lihat: Aimee Dawis, Orang Indonesia Tionghoa mencari Identitas, Jakarta: PT. Gramedia Pustaka Utama, 2010, hlm. 26-27.

${ }^{42}$ Hoo Chang You, Identitas Tionghoa Pasca Soeharto, Jakarta: LP3ES, 2012, hlm 12. 
politik kaum kiri karena RRT adalah negara komunis. Terjadi identifikasi yang melekat dan umum antara etnis Tionghoa dengan komunisme. Stigma sebagai Tionghoa karena telah terlibat dalam kudeta komunis 1965 dianggap menular dan menurun ke generasi selanjutnya.

Pengakuan terhadap identitas kultural tersebut merupakan salah satu bagian dari "masalah Tionghoa" yang belum terselesaikan. "Masalah Tionghoa" di Indonesia sangat berkaitan dengan sikap dan kebijakan pemerintah yang tidak cukup tegas dalam persoalan kewarganegaraan orang-orang keturunan Tionghoa.Pada masa Orde Baru, pemerintah menetapkan kebijakan asimilasi sebagai solusi untuk mengatasi "masalah Tionghoa". Kebijakan asimilasi ini pada dasarnya menganjurkan orangorang keturunan Tionghoa di Indonesia agar membaur dengan masyarakat lokal. ${ }^{43}$ Dengan diterimanya program asimilasi sebagai solusi nasional untuk mengatasi "masalah Tionghoa", maka pada saat yang bersamaan dikeluarkan beberapa regulasi yang mendukung kebijakan asimilasi

43 Paham asimilasi ini dikembangkan dan diperjuangkan oleh LPKB (Lembaga Pembina Kesatuan Bangsa) dan dilanjutkan oleh Bakom PKB (Badan Komunikasi Penghayatan Kesatuan Bangsa). Lihat: Charles A Copel, Tionghoa Indonesia dalam Krisis hlm 92-99. tersebut, yaitu melalui Instruksi Presiden No. 14/1967. ${ }^{44}$

Instruksi ini berkaitan dengan pembatasan aktifitas yang berhubungan dengan agama, kepercayaan, dan adat istiadat keturunan Tionghoa. Instruksi Presiden ini bertujuan melikuidasi pengaruh seluruh kebudayaan Tionghoa, termasuk kepercayaan, tradisi, adat istiadat, dan agamanya. Keluarnya Instruksi Presiden (Inpres) No. 14 Tahun 1967 yang menyatakan adat istiadat orang Tionghoa dilarang dipertontonkan di depan umum, membuat keturunan Tionghoa tidak bebas melestarikan budaya leluhurnya di Indonesia. Tidak hanya itu, pelestarian budaya leluhur orang-orang keturunan Tionghoa dikhawatirkan oleh pemerintah akan mengganggu proses program asimilasi yang dicanangkan oleh pemerintah Orde Baru. Kebijakan asimilasi yang diterapkan oleh Soeharto mengakibatkan pengikisan bahasa serta kebudayaan Tionghoa.

Organisasi-organisasi yang berkaitan dengan ketionghoaan dibubarkan dan sekolah Tionghoa ditutup. Hal itu sejalan dengan kebijakan asimilasi ini. Kebijakan asimilasi di Indonesia merupakan

\footnotetext{
${ }^{44}$ Rahardjo, Alfian Hamzah, editor, Kapok Jadi Nonpri: Warga Tionghoa Mencari Keadilan , Bandung: Zaman Wacana, 1998, hlm. 86-87.
} 
kebijakan yang paling radikal karena kebijakan tersebut telah menghilangkan tiga pilar yang menyangga keberadaan masyarakat dan identitas kultural orang-orang keturunan Tionghoa, yaitu sekolah, media massa, dan asosiasi-asosiasi orang-orang keturunan Tionghoa. ${ }^{45}$

Tidak hanya itu, mereka yang ingin mendirikan rumah ibadah (kelenteng) juga tidak diperbolehkan. Yang masih diperbolehkan hanya memperbaiki, mengecat, atau memelihara kelenteng yang sudah ada. Istilah kelenteng yang menunjukkan tempat ibadah orang Tionghoa tidak lagi boleh digunakan dan diganti dengan Wihara (tempat ibadah umat Budha). Orang-orang keturunan Tionghoa juga diharuskan mengganti nama Tionghoanya dengan nama-nama yang digunakan oleh orang Indonesia untuk memudahkan program asimilasi serta diharuskan berpindah keyakinan agama ke agama Islam, Buddha, Kristen atau Katholik (bukan Khonghucu) karena agama Khonghucu pada saat itu tidak diakui oleh pemerintah.

D. Implikasi Inpres No 14 Tahun 1967 Terhadap Identitas Muslim Tionghoa Cirebon

\section{1) Penggantian Nama}

$\begin{array}{rlr}\text { Salah } & \text { satu } & \text { ketentuan } \\ \text { pemerintah } & \text { dalam } & \text { rangka }\end{array}$ menerapkan politik asimilasi atau pembauran terhadap orang-orang keturunan Tionghoa di Indonesia adalah dengan penggantian nama.Upaya penggantian nama mengacu pada Keputusan Presidium Kabinet No. 127/U/Kep/12/1966 mengenai kewajiban ganti nama bagi masyarakat yang memakai nama Tionghoa. Hal ini ditujukan untuk meyakinkan nasionalisme orangorang Tionghoa kepada Indonesia. Mereka dihimbau untuk mengganti namanya dengan nama Indonesia. ${ }^{46}$

Hampir semua WNI-Tionghoa mengganti nama mereka menjadi nama Indonesia setelah keputusan ini dikeluarkan. Penggantian nama pada saat itu berhubungan dengan penggunaan Surat Bukti Kewarganegaraan Republik Indonesia (SBKRI). Kedudukan SBKRI ini dalam mengurus hal-hal administrasi bagi orang Tionghoa adalah hal yang penting. Orang-orang Tionghoa di Cirebon rata-rata merespon dengan baik peraturan ganti nama tersebut. Sebagian besar orang-orang Tionghoa mengetahui dan melaksanakannya. Akan tetapi, tetap saja ada beberapa golongan kecil yang lebih memilih untuk mempertahankan nama asli mereka,

\footnotetext{
${ }^{46}$ Dawis, op. cit., hlm. 28-29.
}

${ }^{45}$ Dawis Amee, op. cit., hlm. 27-28. 
yang merepresentasikan kebanggaan dan loyalitas terhadap budaya leluhur mereka.

Peraturan ganti nama ini selain menimbulkan generasi keturunan Tionghoa dengan nama Indonesia, juga memunculkan generalisasi dalam penggunaan nama. Pada saat pemerintah Indonesia mengeluarkan anjuran ganti nama, pemerintah juga mengeluarkan beberapa nama yang bisa digunakan oleh orang-orang keturunan Tionghoa. Umumnya nama-nama tersebut menggunakan bahasa Indonesia yang mengandung unsur dari bahasa Jawa dan lazim digunakan oleh masyarakat Indonesia pada waktu itu seperti yang dialami juga oleh Darma Suryapranata yang ikut melaksanakan peraturan tersebut untuk melakukan pergantian nama dari nama Tionghoanya. ${ }^{47}$

Orang-orang Tionghoa di Cirebon relatifnya memilih nama dengan beberapa pertimbangan yaitu menggunakan nama pilihan sendiri yang biasanya menyelipkan karakter marga mereka dalam nama Indonesia, mengkombinasikan dengan nama dari istilah Jawa atau Indonesia dan mengganti keseluruhan nama dengan nama-

\footnotetext{
${ }^{47}$ Wawancara dengan Pak Darma Suryapranata di kediaman narasumber Jl. Siliwangi, No 54 tanggal 06 Juni 2016 pukul 11.00 WIB.
}

nama Islam ketika mereka menjadi muslim.

Beberapa cara yang digunakan orang-orang keturunan Tionghoa dalam memilih dan menggunakan nama Jawa antara lain:

a. memilih nama Jawa yang memiliki karakter marga keluarga mereka. Contohnya: Liem Djai Ling menjadi Salim Drajat, keluarga dari marga Tan menjadi Tanoedibjo, dan lain-lain. Orang Tionghoa yang memilih nama tersebut biasanya tidak ingin menghilangkan nama marganya;

b. memilih nama Jawa yang mempunyai makna yang sama dengan nama Tionghoa mereka. Contohnya: Ong Kha Seng yang artinya keluarga yang sukses, memilih nama Jawa Rahardi Trisno Santoso.

c. Pemilihan nama Indonesia hampir sama dengan pemilihan nama Jawa sebagai ganti nama Tionghoa. Tujuan utama pemilihan nama tersebut adalah agar lebih mudah dalam mengurus administrasi. Contohnya Am Yo menjadi Amin Cahyono, Can menjadi Candra, Lim menjadi Salim.. Pada kasus lain, sebagian orang Tionghoa yang telah menjadi muslim juga 
menggunakan nama yang identik dengan nama-nama Islam seperti yang terjadi pada salah satu narasumber dalam penelitian ini yaitu Harry Saputra Ghani. Penggunaan nama Ghani yang diambil dari salah satu Asmaul Husna yatiu al-Ghaniy yang berarti kaya.

\section{2) Penyelenggaraan \\ Istiadat dan}

Keagamaan

Dalam Instruksi Presiden No 14 Tahun 1967 ditetapkan bahwa semua upacara agama, kepercayaan, dan adat-istiadat Tionghoa hanya boleh dirayakan di lingkungan keluarga dan dalam ruangan tertutup.setelah keluarnya Inpres No.14 tahun 1967 agama Khong $\mathrm{Hu}$ Chu yang dianut oleh etnis Tionghoa beserta hal-hal yang berkaitan dengan perayaan-peryaan hari besar agama Konghucu dilarang ditampilkan di depan umum dan hanya boleh dilakukan secara intern saja.Instruksi tersebut menyebabkan semua perayaan tradisi dan keagamaan kelompok keturunan Tionghoa, termasuk Tahun Baru Imlek, dan Cap Go Meh tidak boleh dirayakan secara terbuka. Pelaksanaan kegiatan upacara keagamaan dan perayaan hari raya orang-orang keturunan Tionghoa sangat dibatasi.Di Cirebon sendiri pada masa Orde Baru menurut penuturan Surya Darmapranata, pernah terjadi satu kasus dimana orang Tionghoa mendapatkan pelarangan dari aparat polisi ketika akan merayakan Imlek dan barongsai.Selain harus melewati birokrasi yang rumit, terjadi pula bahwa setiap tahap birokrasi yang dilalui memang membutuhkan dana yang besar. Bahkan, ketika pertunjukan barongsai sudah siap untuk dipentaskan, Surya Darmparanata masih berada di Kapolresta untuk mengurus perizinan yang masih dihalangi. Namun,karena Surya Darmapranata sendiri telah menjalin hubungan baik dengan Keraton Kasepuhan serta Banser NU, sehingga pementasan barongsai tetap dilaksanakan dengan pengawalan dari kedua elemen tersebut meskipun tanpa mengantongi izin dari aparat polisi. ${ }^{48}$

\section{E. Penutup}

Dikeluarkannya

Intruksi Presiden No 14 tahun 1967 oleh pemerintah Orde Baru dengan latar belakang bahwa orang-orang Tionghoa menjadi dalang dari beberapa peristiwa atau konflik yang terjadi, dan pada masa Soeharto, perstiwa G30S/PKI menjadi alasan

\footnotetext{
${ }^{48}$ Wawancara dengan Pak Darma Suryapranata di kediaman narasumber Jl. Siliwangi no 54 Kota Cirebon tanggal 06 Juni 2016 Pukul 11.00 WIB.
} 
untuk mengasimilasi seluruh etnis Tionghoa baik peranakan maupun totok yang ada di Indonesia agar tidak identik lagi dengan Tiongkok yang dalam ideologinya memegang ideologi komunsime. Sehingga program asimilasi yang diusung oleh pemerintah Orde Baru meliputi agama, adat istiadat, kepercayaan yang terikat dengan leluhurnya yaitu Tiongkok dihapuskan.

\section{Daftar Pustaka}

Afif, Afthonul. 2012.Identitas Tionghoa Muslim

Indonesia.

Depok:Penerbit Kepik

Chambert Loir,Henri dalam Hasan Muarif Ambary.2011. Panggung Sejarah, Jakarta: Yayasan Pustaka OborChang You,Hoo. 2012.Identitas Tionghoa Pasca Soeharto. Jakarta: LP3ES

Coppel, Charles A. 2012. Tionghoa Indonesia Dalam Krisis.

De Graf, HJ. 2004. CinaMuslim di Jawa antara Abad XV dan XVI. Yogyakarta: PT Tiara Wacana

Daradjadi. 2012. Geger Pecinan 17401743, Jakarta: PT Kompas Media NusantaraDawis,Aimee. 2010.Orang Indonesia Tionghoa mencari Identitas.Jakarta: PT. Gramedia Pustaka Utama
Dinas Kebudayaan dan Pariwisata Jawa Barat. ed: A. Sobana Hardjasaputra \& Tawalinuddin Haris. 2011.Cirebon Dalam Lima Zaman.

Giap, The Siauw. 1986.Cina Muslim di Indonesia. Jakarta: Yayasan Ukhuwah Islamiyah.

Koentjaraningrat. 2009. Pengantar Ilmu Antroplogi. Jakarta:Rineka Cipta.

Kuntowijoyo, 1995. Pengantar Ilmu Sejarah. Yogyakarta: Yayasan Bentang Budaya.

Suryadinata, Leo. 2010. Tokoh Tionghoa dan Identitas indonesia: dari Tjoe Bou San sampai Yap Thiam Hien. Jakarta: Komunitas Bambu.

Suryadinata,Leo. 2005. Pemikiran Politik Etnis Tionghoa Indonesia1900-2002.Jakarta: LP3ES.

Suryadinata,Leo. 2002.Dilema Minoritas Tonghoa. Jakarta: PT Grafiti Pres

\section{Jurnal dan Artikel}

Michael Jacobsen. 2003.Chinese Muslims in Indonesia: Politics, economics, faith and expediency, dalam Southeast Asia Research Centre, No.54. 
Muhamad Ali. 2007.Chinese Muslim in Colonial and Post Colonial Indonesia, dalam jurnal Special Edition: Islam in Southeast Asia, Volume 7, Issue 2.

Priyanto Wibowo, Tionghoa Dalam Keberagaman Indonesia: Sebuah Perspektif Historis Tentang Posisi Dan Identita, dalam Jurnal Prosiding The $4^{\text {th }}$ International Conference on
Indonesian Studies: "Unity, Diversity and Future", Fakultas Ilmu Budaya Universitas Indonesia.

Novita. Perkembangan Etnis China Muslim di Cirebon. Diposting pada 2005. http://portalcirebon.blogspot.co.i d/2014/01/perkembangan-etnischina-muslim- .html/m=1 